\title{
Inequality and Industrial Wage Change in Brazil
}

\author{
by \\ Paulo du Pin Calmon, Pedro Conceição and James K. Galbraith
}

pcalmon@nutecnet.com.br, pedroc@uts.cc.utexas.edu, Galbraith@mail.utexas.edu

\author{
Calmon: University of Brasilia \\ Brasilia, DF Brazil
}

Conceição and Galbraith: LBJ School of Public Affairs

The University of Texas at Austin

Austin, Texas 78713

UTIP Working Paper Number 12

July 16, 1999

\begin{abstract}
This paper has been prepared for presentation at the Brazilian Economists Conference in Rio, September, 1999, and has been rated as one of the eight top submissions to that event. It is a project of the University of Texas Inequality Project, http://utip.gov.utexas.edu, and is copyright (c) 1999 by the authors.
\end{abstract}

\begin{abstract}
This paper focuses on two questions. First, how did inequality in the industrial wage structure of Brazil evolve from 1985 to 1995? Second, what is the relationship between these dynamics and economic policy? We display the evolution of wage inequality in Brazil and relate this evolution to changing macroeconomic conditions. Our analysis suggests that there is a strong relation between rising inequality and the restructuring of the Brazilian economy that occurred in the middle 1980's.
\end{abstract}

$1^{\text {st }}$ Version- 06/04/97

This version: July, 1999 


\section{1- Introduction}

Since the early 1970s, the relation between income inequality and economic policy has been the focus of a heated debate in Brazil. This debate has been fueled by research showing that income inequality in Brazil has continued to worsen. As Table 1 shows, the Gini coefficient for Brazil (as measured from national data sources) has been growing almost steadily since 1960 .

Table 1

Evolution of the Gini Coefficient and GDP Per Capita in Brazil

$1960-95$

\begin{tabular}{ccc}
\hline & Gini Coefficient & $\begin{array}{l}\text { Average } \\
\text { in GDP Per Capita (\%) }\end{array}$ \\
\hline $1960-70$ & 0.50 & 3 \\
$1970-80$ & 0.56 & 6 \\
$1980-90$ & 0.58 & 0.4 \\
$1990-93$ & 0.61 & -0.6 \\
$1993-95$ & 0.59 & 3.5 \\
\hline
\end{tabular}

Source: IBGE

Attempts to explain this evolution fall broadly into three different major groups. A first group focuses on the relation between income inequality and individual abilities; this group includes studies based on the Kuznets hypothesis, as well as on variations of human capital theory ${ }^{1}$. A second group has attempted to link inequality with institutional aspects of the Brazilian labor market, capitalizing on the well-known fact that labor relations in Brazil are ruled by a rigid legal framework ${ }^{2}$. Finally, there are studies that relate inequality to imperfections in the labor market; such studies explore the existence of efficiency wages, implicit contracts, labor hoarding and industrial rents ${ }^{3}$.

${ }^{1}$ See Langoni (1973) and Leal and Wergang ( 1991).

${ }^{2}$ Saboia (1991) and Amadeo e Camargo (1994) are examples of these studies.

${ }^{3}$ See, for example, Ramos (1993). 
The present study focuses specifically on two questions: a) how did inequality in industrial wage structure evolve from 1985 to 1995 ? and b) what is the relationship between these dynamics and economic policy? Section 2 displays the evolution of wage inequality in Brazil and attempts to relate this evolution to changing macroeconomic conditions. Section 3 suggests that there is a relation between inequality and the restructuring of the economy that occurred in the middle 1980s. Major conclusions are summarized in section 4 .

\section{2- Industrial wage inequality and macroeconomic conditions}

Although there exists a large amount of work on income distribution in Brazil, there have been only a few attempts to study the inequality of wages. Among these, Langoni (1973) attempted to identify the sources of total wage inequality and, through a sector-wise decomposition of the Theil's T statistic, found that differences in income between sectors of activity accounted for almost 15\% of total inequality between 1960

and 1970. Later, Ramos (1995) found that wage inequality between industries accounted for almost $20 \%$ of total income inequality during the 1980 s.

These studies have provided a useful index of inter-sectoral income inequality at any given moment of time. But they suffer from two deficiencies. First, the definition of sectoral boundaries is arbitrary, so that the attribution of inequality of "between" and "within" group sources will vary if a different industrial taxonomy is chosen. Second, such studies do not provide insight into the evolution of inequality, even though their methods are adaptable for this purpose. Using a similar decomposition of the Theil's T but restricting ourselves to the between-group component, we obtained a measure of wage inequality in Brazil on a monthly basis. Therefore, unlike other studies, our focus was not on the sources of income inequality, but on how income inequality evolves over time and how it relates to other economic variables. In this paper, we first analyze the evolution of our inequality measure during five periods with distinctively different macroeconomic 
contexts. Second, we discuss the relationship between wage inequality and important macroeconomic variables.

2.1- Inequality and phases in macroeconomic development

Our measure of inequality is based on the monthly series of industrial wages in seventeen major industrial sectors from 1976 through 1995, gathered by IBGE ${ }^{4}$, the Instituto Brasileiro de Geografia e Estatistica. Using the group-wise decomposition of the Theil's T statistic, we estimated the evolution of inequality of manufacturing wages by adopting the between group component of the $\mathrm{T}$ statistic ${ }^{5}$, providing us with lower bound estimates of overall wage inequality. Results of this calculation are presented in Figure 1 below, first reported in Calmon, Conceição, Galbraith, Cantu and Hibert (1997). As we argue in that paper, there is a distinctive pattern in the evolution of the inequality index which is meaningfully related to macroeconomic developments. ${ }^{6}$

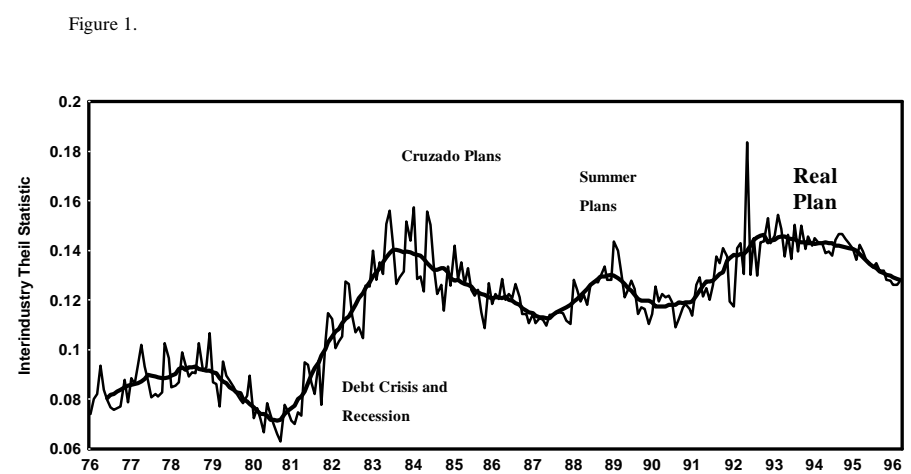

Figure 1- The Evolution of the Theil Index for Industrial Earnings in Brazil.

${ }^{4}$ It is worth saying that from 1976 through 1985 wage data was presented by IBGE in a nominal basis. After that only real changes in wages was presented.

${ }^{5}$ Details of the methodology adopted are in Calmon, Conceiçao, Galbraith, Cantu and Hibert (1997).

${ }^{6}$ This link is also partially supported by the findings of Bonelli and Ramos (1994). Using a full Theil statistic for measuring total inequality the authors found that between 1976 and 1990 the direction of changes in the inequality statistic and in GDP per capita were strongly correlated. 
The developments illustrated in Figure 1 can be clearly divided in five distinctive phases:

- Debt-led growth 1976 to 1980 - During this period, the Brazilian economy was heavily affected by the first oil shock, which caused a strong deterioration in the terms of trade. On the other hand, there was a massive inflow of foreign capital that sustained the import substitution investment strategy of growth. Capital deepening caused an increase in industrial wages. Inequality decreased during these years, reaching a low for this time frame at the turn of the 1980 s.

- Orthodox phase 1981 to 1984 - Balance of payment problems resulted in the adoption of very restrictive fiscal and monetary policies under the supervision of the IMF. Nevertheless, there was no significant reduction in inflation while the economy advanced into a recession. Concurrently, great emphasis was given to export promotion, through changes in the exchange rate regime and the creation of fiscal and credit incentives. Recession cum export promotion had an asymmetrical impact on the industrial sector: a decrease in domestic consumption combined with an expansion of almost $60 \%$ in manufactured exports. Wage inequality increased sharply and continuously during this period.

- Heterodox period 1985 to 1987 - The orthodox policy strategy was abandoned in 1985, immediately after the first civil government in almost twenty years took office. Growth became a priority and heterodox measures against inflation were adopted: the Cruzado Plan (February 1986) and the Bresser Plan (June 1987). These plans combined a temporary price freeze with measures targeted to increase investments. As a consequence, the annual GDP growth rate reached 8.3\% in 1985, 7.5\% in 1986 and $3.6 \%$ in 1987 . Despite the ingenuity of the heterodox plans, inflation rates remained very high during the whole period, reaching $235 \%$ per year in 1985 , decreasing somewhat during the Cruzado (65\%), but rising again in 1987 (415\% per year). Wage inequality decreased continuously during this period. 
- Full indexation phase (1988-1993) - The failure of the heterodox plans created the fear of hyperinflation. Nevertheless, formal and informal mechanisms of indexation maintained the structure of relative prices somewhat stable, allowing economic activity to continue. During this period, GDP per capita decreased almost $8 \%$. Several attempts were made to control inflation without success: the Summer Plan (January 1989), the Collor Plan (March 1990) and the Collor Plan II (February 1991). Despite these efforts, inflation rate was always over $1,000 \%$ per year, with the exception of 1991, when it reached $500 \%$. A very important development during this period was the change in the trade regime in the early 1990s, with greater emphasis in import liberalization and on economic integration. Wage inequality increased considerably during this period.

- Real Plan (1994-1995) - The Real was implemented in July 1994 and has been, by far, the most successful stabilization program. A monetary reform allowed rapid disinflation (from 2,700\% in 1993 to 15\% in 1995)and a significant increase in GDP per capita (7\% during the period). Import liberalization continued and a new exchange rate regime was implemented. Wage inequality fell during this period, though it remains far above the pre-1980 level.

Brazil has passed through a period of significant changes in its trade regime in recent years. The trade regime had been stable since 1957, marked by high tariffs and other non-tariff barriers (compatible with Brazil's import-substitution style of industrialization). National development plans fueled mainly by borrowing from abroad pushed the level of demand for industrial products, and was the major force determining the level of industrial employment.

This model collapsed during the early 1980s as a consequence of the debt crisis. In the first half of the 1980s the country began to pursue an export promotion strategy, with constant devaluation. Trade surpluses began to appear in the first half of the 80s as the 
economy slipped into recession. Industries began to rearrange their production structures towards the foreign market, but only a few were actually competitive. High inflation, tight credit policies, fiscal deficits and, consequently, a domestic recession, plus a lot of uncertainty about the macroeconomic environment, inhibited any sort of consistent public as well as private investment wave.

The change in the trade regime towards import liberalization begins to take place in 1988 with the end of a series of non-tariffs barriers and a slight, but important, decrease in tariffs. But major changes actually took place since the late 1980s, when steady decreases in tariffs begin to occur. The average tariff that was near 50\% between 1957 and 1987 , decreased to $32.2 \%$ in 1990 and continued to decrease since then, reaching only $11.2 \%$ in 1994 before increasing slightly in 1995 to $13.9 \%{ }^{7}$

In Brazil, the existence of a considerable differential between domestic and international interest rates combined with increased openness to foreign investment created a massive flow of foreign capital. As a consequence, foreign reserves had surpassed US \$50 billion in 1995, producing a considerable exchange rate overvaluation. Taking as a base the real value of the exchange rate in 1989, estimates of real exchange rate overvaluation at the end of 1995 range from $17.6 \%$ (using the production price index from IBGE) to $30 \%$ (using the consumer price index from the University of São Paulo).

After describing the major macroeconomic and political phases that provided the different contexts for the period under analysis, we move below to a more aggregated analysis of changes in inequality, one that associates these changes with the evolution of macroeconomic variables.

${ }^{7}$ Moreira, Mauricio and Paulo Correa." Abertura Comercial e Indústria: o que se pode esperar e o que se vem obtendo". Texto para Discussão n.49. BNDES: Rio de Janeiro, 49, 1996. 
2.2- Inequality and the evolution of macroeconomic variables

Calmon, Conceição, Galbraith, Cantú and Hibert (1997) discuss the relations between inequality and growth and inflation. Changes in inequality of manufacturing wages between 1976-95, measured by the lower bound Theil, are strongly associated with GDP growth. Recoveries tend to be equalizers, and recessions seem to generate increasing inequality. No significant year-over-year relation was found between inequality and inflation, although it seems likely that inflation strongly increased inequality within-years, during the periods of hyper-inflation and full indexation. ${ }^{8}$

The relationship between GDP per capita and the lower bound Theil can be represented by the following equation:

$$
\mathrm{T}^{\prime}=5.575-2.264 \mathrm{Y}
$$

with $R^{2}=0.56$ and Durbin Watson $=1.42$. Both values of $t$ (in parentheses) are significant at the $1 \%$ level. T' is a variable that represents changes in the lower-bound Theil estimate between 1976 and 1995, and Y represents changes in GDP per capital during the same period. The above regression confirms the inverse relation between growth and inequality, but it explains only about $50 \%$ of total variation in inequality. This result suggests that, in addition to GDP per capita , there are other important variables that have affected wage inequality in Brazil significantly. The complexity of the evolution of the income distribution in Brazil is further illustrated by analyzing the growth of earnings in all sectors by deciles between 1985 and 1995, as shown in Table 2 .

${ }^{8}$ The absence of a clear relation between wage inequality and inflation is a somewhat surprising result, given that there is a clear relation between total inequality and inflation. As pointed out by Cardoso (1992), the inflation tax has a very adverse impact on the poor, mainly because the poor has less flexibility that better-off groups in the timing of purchases and second that the poor are less able to protect their income from erosion through indexation of wages. 
Table 2

Growth of income by deciles of the distribution of income

\begin{tabular}{lrrrr}
\hline & $1985-86$ & $1986-90$ & $1990-93$ & $1993-95$ \\
\hline first tenth (poorest) & 95.9 & -40.8 & -12.7 & 99.9 \\
second tenth & 44.2 & -32.8 & 22.5 & 46.4 \\
third tenth & 49.1 & -37.7 & 35.1 & -1.8 \\
fourth tenth & 32.4 & -35.3 & 12.1 & 31.7 \\
fifth tenth & 44.7 & -31.0 & -2.1 & 37.2 \\
sixth tenth & 42.6 & -29.9 & -1.1 & 27.3 \\
seventh tenth & 41.2 & -27.3 & -7.4 & 33.6 \\
eight tenth & 38.6 & -25.0 & -9.0 & 34.0 \\
ninth tenth & 33.7 & -23.4 & -9.0 & 33.9 \\
ten tenth (richest) & 39.4 & -25.1 & -3.3 & 24.6 \\
\hline \multicolumn{4}{c}{ Source: IBGE }
\end{tabular}

Table 2 shows that there was a somewhat homogeneous trend in income distribution during the 1980s, and indicates that the poorest were particularly hurt during the full indexation phase. Although income fell for all groups during the late 1980s, it fell more significantly in the bottom deciles. During the 1990s this somewhat homogeneous trend seems to have changed abruptly, with smaller changes and greater dispersion in growth rates by decile. By 1993 the middle income groups were able to attain a significant gain despite the decrease of income in the higher group and negative rates of growth in per capita GDP. This behavior suggests the existence of a more complex process taking place during the 1990s.

In the next section, we attempt to shed more light on the complex evolution of wage inequality, by focusing on industry specific factors related to structural changes in the economic environment. 


\section{3 - Inequality and the restructuring of the Brazilian economy}

Perhaps the most striking feature of the recent evolution in Brazilian manufacturing industries is the continuous decrease of its share of total product ${ }^{9}$. In 1985, manufacturing production represented almost 34\% of the total GDP. In 1995 this share had decreased to just $22 \%$.

This decrease was in part a consequence of the expansion in the services sector in the economy, but it was also a response to macroeconomic developments. The persistence of inflation created an enormous incentive for the expansion of the Brazilian financial system, specially the money-management related services, whose share of GDP grew from $5 \%$ in the mid-70s to almost $20 \%$ in $1989^{10}$. Resources dedicated to these activities have been stolen by inflation from other productive sectors in the economy, especially from industry. This development also strengthened the process of concentration of income and wealth, given that the poor not only do not have assess to money management services, but also rarely find jobs in the financial services sector.

This section is organized in three parts. The first part describes the major changes in the evolution of wages and in employment in the different manufacturing sectors. In the second part, we attempt to identify major factors responsible for the restructuring, focusing on changes in productivity and on macroeconomic policy development issues such as trade liberalization. Finally, in the third part, further insights on the effects of the restructuring process on inequality are derived from a comparison of the evolution of fixed and variable weighted Theil measures.

${ }^{9}$ In most of this section we ignore the period prior to 1985 as some methodological changes in the way the wage data is collected were made by IBGE. We are confident that these changes have not affected the estimates of the Theil statistics in any meaningful way.

${ }^{10}$ See Silva (1991). 
3.1- Evolution of wages and employment in the manufacturing sectors

Real wages and employment in the manufacturing industries have changed considerably between 1985 and 1995. Table 3 presents the evolution of these variables during this period.

Table 3

Evolution of real wages and employment 1985-1995 (\% change)

\begin{tabular}{|lcc|}
\hline Industrial Sectors & Wages & Employment \\
\hline Total & 15.1 & -17.3 \\
Non-Metallic. & 20.8 & -16.6 \\
Metallurgy & 9.1 & -13.6 \\
Mechanic & 16.0 & -17.6 \\
Electric Equipt & 14.6 & -20.1 \\
Transport Material & 20.5 & 4.0 \\
Wood & 3.9 & -34.2 \\
Furniture & 11.9 & -26.0 \\
Paper & 17.5 & -15.6 \\
Rubber & 7.6 & 5.6 \\
Leather & -4.2 & -28.9 \\
Chemical & 15.5 & -27.7 \\
Pharmaceutical. & 11.8 & 9.6 \\
Perfumes and soaps & 1.3 & 22.4 \\
Plastic & 4.5 & -0.2 \\
Textile & 5.0 & -16.4 \\
Garments & 10.6 & -45.0 \\
Food & 8.2 & -8.3 \\
Beverage & 9.6 & 3.5 \\
Tobacco & 39.8 & -31.6 \\
Edit orial $\quad$ and & 11.6 & -4.6 \\
Graphic & & \\
Others & 17.3 & -0.8 \\
& Source: IBGE &
\end{tabular}

As the table shows, real wages have grown considerably in almost every sector, but employment has shown a consistent decrease. There are also striking differences in performance between industrial sectors. These differences are summarized in Table 4, which compares the wage and employment performance in each sector to the average of 
the manufacturing sector. In addition, using the classification adopted by Pinheiro et al. (1994) each industrial sector is labeled as capital intensive (K) or labor intensive (L).

Table 4

Evolution of relative wages and relative employment

1985-1995

\begin{tabular}{|c|c|c|}
\hline & $\begin{array}{l}\text { Relative } \\
\text { Employment } \\
\text { Expansion }\end{array}$ & $\begin{array}{l}\text { Relative } \\
\text { Employment } \\
\text { Contraction }\end{array}$ \\
\hline $\begin{array}{c}\text { Relative Wage } \\
\text { Growth }\end{array}$ & $\begin{array}{l}\text { Transport Material } \\
\text { (K) }\end{array}$ & $\begin{array}{l}\text { Tobacco (K) } \\
\text { Non-Metallic (L) } \\
\text { Paper (K) } \\
\text { Mechanic (L) } \\
\text { Chemical (K) } \\
\text { Others (L) } \\
\end{array}$ \\
\hline $\begin{array}{l}\text { Relative Wage } \\
\text { Decrease }\end{array}$ & $\begin{array}{l}\text { Pharmaceutical (K) } \\
\text { Beverage }(\mathrm{K}) \\
\text { Rubber }(\mathrm{K}) \\
\text { Perfume }(\mathrm{K})\end{array}$ & $\begin{array}{l}\text { Electric Equipt (K) } \\
\text { Furniture (L) } \\
\text { Edit. and Graphic(L) } \\
\text { Garment (L) } \\
\text { Metallurgy (K) } \\
\text { Food (L) } \\
\text { Textile (L) } \\
\text { Plastic (L) } \\
\text { Wood (L) } \\
\text { Leather (L) }\end{array}$ \\
\hline
\end{tabular}

Several interesting results appear. First, only the transport material sector (automobiles, trucks, parts, etc.) experienced employment and relative wage growth simultaneously. All industries that displayed an expansion in employment were capital intensive. On the other hand, most of the sectors that exhibited a concurrent contraction in employment and relative wages were labor intensive. The most labor intensive sectors, such as textile, garments, leather and wood products, had a dismal performance in terms of wages and employment during this period.

The performances depicted in these tables were not steady over time. Table 5 presents the evolution of relative wages during the three sub-periods under study: the heterodox period (1985-87), the full indexation phase (1988-92) and the Real Plan (199495). None of the seventeen manufacturing industries had a consistent behavior during these three periods. All industries which underwent a decrease in their relative wages 
between 1985-95 had an increase in their relative position at least in one of the subperiods. Even the transport material industry, which displayed a simultaneous growth in terms of wages and employment, only had such a performance because of gains in its relative position in only one specific sub-period - 1988-93.

Table 5

Evolution of relative wages

1985-95

\begin{tabular}{|lccc|}
\hline \multicolumn{1}{|c}{ Industrial Sectors } & $1985-87$ & $1988-93$ & $1994-95$ \\
\hline Total & 1.0000 & 1.0000 & 1.0000 \\
Non-Metallic. & 1.0276 & 0.9563 & 1.0674 \\
Metallurgy & 0.9618 & 1.0666 & 0.9240 \\
Mechanic & 0.9952 & 1.0464 & 0.9678 \\
Electric Equipt & 0.9694 & 1.0818 & 0.9490 \\
Transport Material & 0.9651 & 1.1107 & 0.9763 \\
Wood & 0.9138 & 0.9854 & 1.0021 \\
Furniture & 0.9846 & 0.9192 & 1.0742 \\
Paper & 1.0007 & 0.9473 & 1.0770 \\
Rubber & 0.8950 & 0.9874 & 1.0579 \\
Leather & 0.9105 & 0.8354 & 1.0943 \\
Chemical & 1.0089 & 1.0381 & 0.9579 \\
Pharmaceutical. & 0.8880 & 1.1243 & 0.9723 \\
Perfumes and soaps & 0.8760 & 1.0434 & 0.9622 \\
Plastic & 1.0052 & 0.9111 & 0.9913 \\
Textile & 1.0091 & 0.9360 & 0.9658 \\
Garments & 1.0413 & 0.9061 & 1.0180 \\
Food & 0.9820 & 0.9273 & 1.0323 \\
Beverage & 0.9883 & 0.9083 & 1.0607 \\
Tobacco & 0.9850 & 1.2514 & 0.9852 \\
Editorial and Graphic & 0.9235 & 0.9608 & 1.0929 \\
Others & 1.0181 & 0.9887 & 1.0122
\end{tabular}

3.2- Factors influencing the restructuring of the manufacturing sectors

The differences between sectors confirm that there are important industry-specific factors affecting wage inequality. One possibility is to consider changes in productivity as 
one of these factors. Table 6 presents data for changes in productivity in the manufacturing sector of the State of São Paulo, which we use here as a proxy for the changes in the whole of Brazilian industry. ${ }^{11}$

Table 6

Changes in productivity in the manufacturing sector

1986-1995

State of São Paulo

\begin{tabular}{|lrrrr|}
\hline \multicolumn{1}{|c}{ Industrial Sectors } & $1986-87$ & $1988-89$ & $1990-93$ & $1994-95$ \\
\hline Total manufacturing & $-4.65 \%$ & $1.43 \%$ & $15.77 \%$ & $13.25 \%$ \\
Non-Metallic. & $-3.09 \%$ & $-0.56 \%$ & $4.46 \%$ & $27.50 \%$ \\
Metallurgy & $-6.16 \%$ & $6.28 \%$ & $6.65 \%$ & $16.52 \%$ \\
Mechanic & $8.78 \%$ & $-15.64 \%$ & $14.15 \%$ & $6.99 \%$ \\
Electric Equipt & $-12.56 \%$ & $4.75 \%$ & $30.17 \%$ & $21.94 \%$ \\
Transport Material & $-14.61 \%$ & $3.45 \%$ & $14.35 \%$ & $11.66 \%$ \\
Paper & $7.08 \%$ & $15.06 \%$ & $18.55 \%$ & $18.53 \%$ \\
Rubber & $-4.42 \%$ & $-3.17 \%$ & $4.75 \%$ & $10.36 \%$ \\
Chemical & $-6.34 \%$ & $-0.71 \%$ & $20.20 \%$ & $13.91 \%$ \\
Pharmaceutical. & $7.68 \%$ & $-11.06 \%$ & $-5.85 \%$ & $25.77 \%$ \\
Perfumes and soaps & $22.02 \%$ & $5.65 \%$ & $15.55 \%$ & $-9.69 \%$ \\
Plastic & $-6.98 \%$ & $13.95 \%$ & $1.84 \%$ & $29.00 \%$ \\
Textile & $-11.77 \%$ & $-5.81 \%$ & $19.99 \%$ & $9.44 \%$ \\
Garments & $-14.90 \%$ & $-8.06 \%$ & $16.26 \%$ & $-0.03 \%$ \\
Food & $1.81 \%$ & $-4.20 \%$ & $7.26 \%$ & $10.10 \%$ \\
Beverage & $27.39 \%$ & $11.40 \%$ & $17.32 \%$ & $34.09 \%$ \\
Tobacco & $5.10 \%$ & $-5.03 \%$ & $-32.47 \%$ & $27.11 \%$
\end{tabular}

The table shows that, along with the reduction in the share of the manufacturing sector in GDP, there was a significant increase in productivity, which expanded almost $30 \%$ between 1990 and 1995. It is worth noting that this is a new phenomenon, specific to the 1990s. Even during the heterodox period (1986-87), when there was a considerable expansion in economic activity, productivity did not increase. Only in the midst of the full indexation phase, a period of great uncertainty, did changes in productivity begin to be noticed.

${ }^{11}$ São Paulo is the most industrialized state in Brazil and responds for $35 \%$ of the Brazilian GDP, and almost half of the manufacturing production. 
To consider 1990 as a turning point in terms of productivity suggests two possible explanations for these relationships. The first one relates gains in productivity to the overall level of economic activity and, therefore, reinforces the hypothesis that inequality and macroeconomic developments are directly related. The existence of implicit contracts or labor hoarding affecting labor demand could explain the asymmetry in response to a recession between sectors. Recession during the early 1990s not only affected GDP per capita, but also industrial production. Manufacturing production had an abysmal performance during this period, with growth rates of $-9 \%$ in $1990,-2.5 \%$ in 1991 and $-4 \%$ in 1992. It is possible to argue that the recession induced restructuring - dumping of labor - which resulted in increases in productivity. In addition to that, the success of the Real Plan after 1994 created new opportunities for investment and growth, and again a differentiated response could have affected the level of productivity in some sectors.

A second possible explanation associates productivity to changes in the trade regime. As pointed out earlier, one of the major characteristics of the Collor Plan, implemented in 1990, was the commitment to trade liberalization. ${ }^{12}$ This commitment was actually transformed into action in 1990, when the country attained a significant increase in imports, causing a reduction in trade surplus to an amount of only US\$ 10 billion, the smallest since 1986.

Trade liberalization has been further advanced by those who succeeded Collor. Imports, which reached an average of only US\$ 15 billion per year during the heterodox period (1985-87), almost tripled, to an average of US\$ 42 billion per year during the first years of the Real Plan (1994-95). As a consequence, trade deficits, which had not been a matter of great concern since the early 1980s, became one of the weakest points of the Plan's performance.

${ }^{12}$ This commitment was also present in the negotiations involving the Mercosul. Although most of the trade agreements were only fully implemented in 1995, there has been, since 1990, an increased trade between the country members. 
Transport material and electric/electronic equipment are the two examples of industrial sectors where increases in productivity were clearly related to changes in the trade regime. Expansion of the market size due to expansion of trade with the Mercosul countries (Uruguay and Argentina), easy access to cheaper inputs from other countries, import competition and fear of losing market share to newcomers coming from abroad all forced companies in these two sectors to invest massively in order to restructure and modernize their production lines.

Traditional companies in the transport material industry - Ford, GM, Fiat and Volkswagen - have been investing to adapt and expand their production lines, while Japanese and Korean companies are advancing plans to install complete production lines in the country. As a consequence, the transport sector not only experienced an expansion in productivity, but also an increase in terms of employment and relative wages. At the same time, productivity at the electric and electronic equipment industry has been expanding, but following a different path. For example, production of TV sets, which reached an average of almost 2 million units per year during the late 1980s, almost tripled in 1995, transforming Brazil into the third largest producer in the world. But, as pointed out in Table 2 above, production and productivity growth had not positively influenced relative wages and labor demand in the industry. In fact, employment in the sector decreased almost $20 \%$ during the 1990 s.

A word of caution is in order about the possible connection between trade and productivity. First, there is no unambiguous relationship between changes in trade regime and in productivity levels; it is very difficult to establish, conceptually or empirically, a clear causality relation between import competition or export promotion and productivity growth. Second, gains in productivity depend, fundamentally, on the level of investment. Therefore changes observed in 1990 can be either induced by changes in economic environment or be a consequence of the lagged effect of incentives to export promotion implemented during the 1980s. Therefore, it is necessary to interpret with caution and 
explore further the convergence between changes in the trade regime and productivity growth during the 1990s.

It is also important to notice that both possible explanations relating changes in productivity to macroeconomic developments or to changes in the trade regime are not necessarily mutually exclusive. Therefore, despite of the need of a clear explanation for changes in productivity it is worth asking how these changes affected labor demand and wage inequality.

In order to study the relation between changes in wages, employment and productivity we regressed the annual growth rates for these variables from 1986 to 1995 for sixteen manufacturing industries $(n=160)$, using a fixed industry and common year effects model such as:

$$
W_{i t}=\alpha_{t}+\beta_{i}+w_{i t}
$$

Where $W_{i t}$ is the growth rate of real wages in industry $\mathrm{i}$ on year t. ${ }^{13}$

Residuals from the covariance model above were named $w_{i t} e_{i t}$ and $p_{i t}$ for wages, employment and productivity respectively. In order to demonstrate the relation between these variables, $w_{i t}$ was regressed on the $e_{i t}$ and $p_{i t}$ and $e_{i t}$ was regressed on productivity ${ }^{14}$. Estimated coefficients are presented below:

$$
\begin{aligned}
& w_{i t}=-0,1384 p_{i t} * ;(-1.7620) \\
& w_{i t}=0.0507 e_{i t} ;(0.6401) \\
& e_{i t}=-0.2458 p_{i t} * * * ;(-5.5128) \\
& * \text { Significant at a } 0.1 \text { level } \\
& * * * \text { Significant at a } 0.01 \text { level }
\end{aligned}
$$

${ }^{13}$ To avoid perfect collinearity among the explanatory variables, only (i-1)+(t-1) dummy variables were added.

${ }^{14}$ A similar procedure was adopted by Kim and Topel (1995) in a study of labor market performance in Korea. 
The first regression suggests the existence of a negative relation between changes in relative productivity and relative wages. However, this relation can only be established at a $10 \%$ significance level. The indication is that an increase of $10 \%$ in relative productivity will actually decrease relative wages in almost $1.4 \%$. The conclusion is that changes in productivity had a small but hurtful effect on the price of labor.

The second equation points to the absence of a significant relation between growing employment and relative wage growth. Thus, there is evidence that the price of labor has not been affected by growing manufacturing sectors.

Finally, the third estimate indicates that there was a meaningful relationship between differences in productivity growth and changes in labor demand. But it is interesting to notice that this relation is negative. In other words, manufacturing industries with greater than average productivity growth actually decreased their labor demand. According to the estimates, a $10 \%$ increase in productivity above the average rate of growth will reduce relative employment by $2.5 \%$ in Brazil. ${ }^{15}$

\section{3- Fixed Theil analysis}

The Theil index is determined at each moment by the wage structure and by the employment structure. The index we have been using throughout this discussion is computed from contemporaneous values of wages and employment. Since the employment figures work as weights for the wage values, this is a variable-weighted Theil index, reflecting the actual measure of inequality at each instant. To investigate the different effects of wages and employment on inequality, we computed also two fixedweighted Theil index series, one based on the structure of employment in January 1976,

${ }^{15}$ These results can be compared with those obtained by Kim and Topel (1995). In contrast with the results obtained for Brazil, the authors found strong indications that in Korea greater productivity growth actually increases labor demand. As in Brazil, the authors found no evidence that growing sectors faced a rising supply price of labor. 
and another based on November 1995. The three series are presented together in Figure 2.

Figure 2- Fixed and Variable Theil Index Series

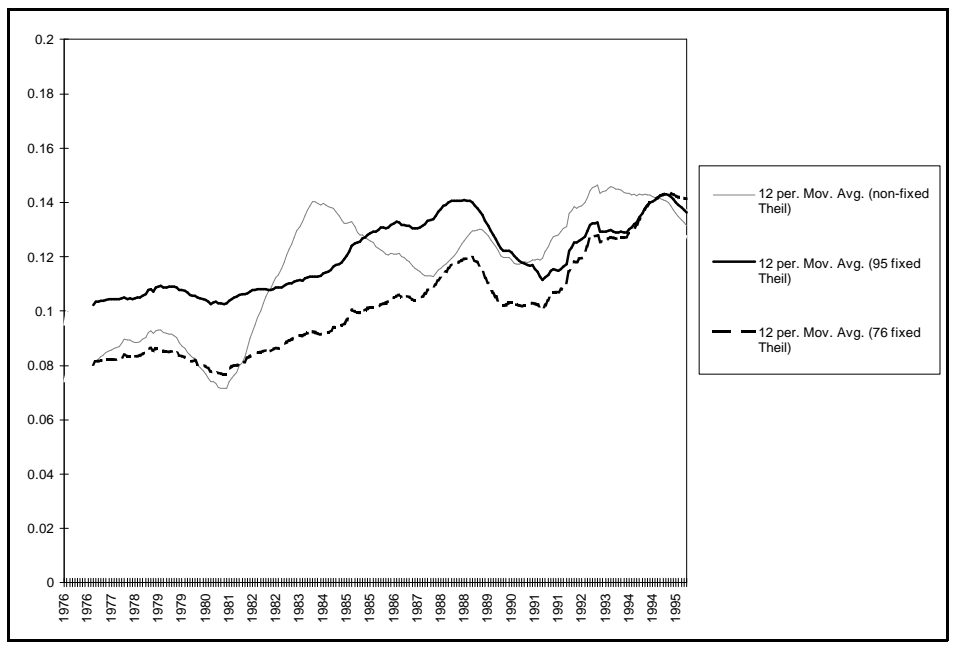

Figure 2 indicates that both fixed Theil series move very similarly, except for a faster increase in the 76-fixed series in the 1990's. Table 7 compares the evolution of the fixed and variable series.

Table 7- Comparison Between the Changes in the Variable and Fixed Theil Series

\begin{tabular}{ll}
\hline \multicolumn{1}{c}{ Period } & \multicolumn{1}{c}{ Series Movement } \\
\hline I- Jan 76-Dec 80 & Similar pattern \\
II- Jan 81-Dec 83 & Both increase, variable more abruptly \\
III-Jan 84-Dec 87 & Variable decreases, fixed keeps increasing \\
IV- Jan 88- Jun 93 & Similar pattern \\
V- July 93-Jun 95 & Variable decreased, fixed increases
\end{tabular}


The differences in the series rate of change in periods II and III reflect, we argue, substantial changes in the manufacturing employment structure in Brazil at these times. Figure 3 traces the levels employment of the manufacturing sectors, extending the analysis of section 3.1. Figure 3 confirms that, besides the overall loss in employment from 1976 to 1995 , substantial oscillations occurred, particularly in periods II and III.

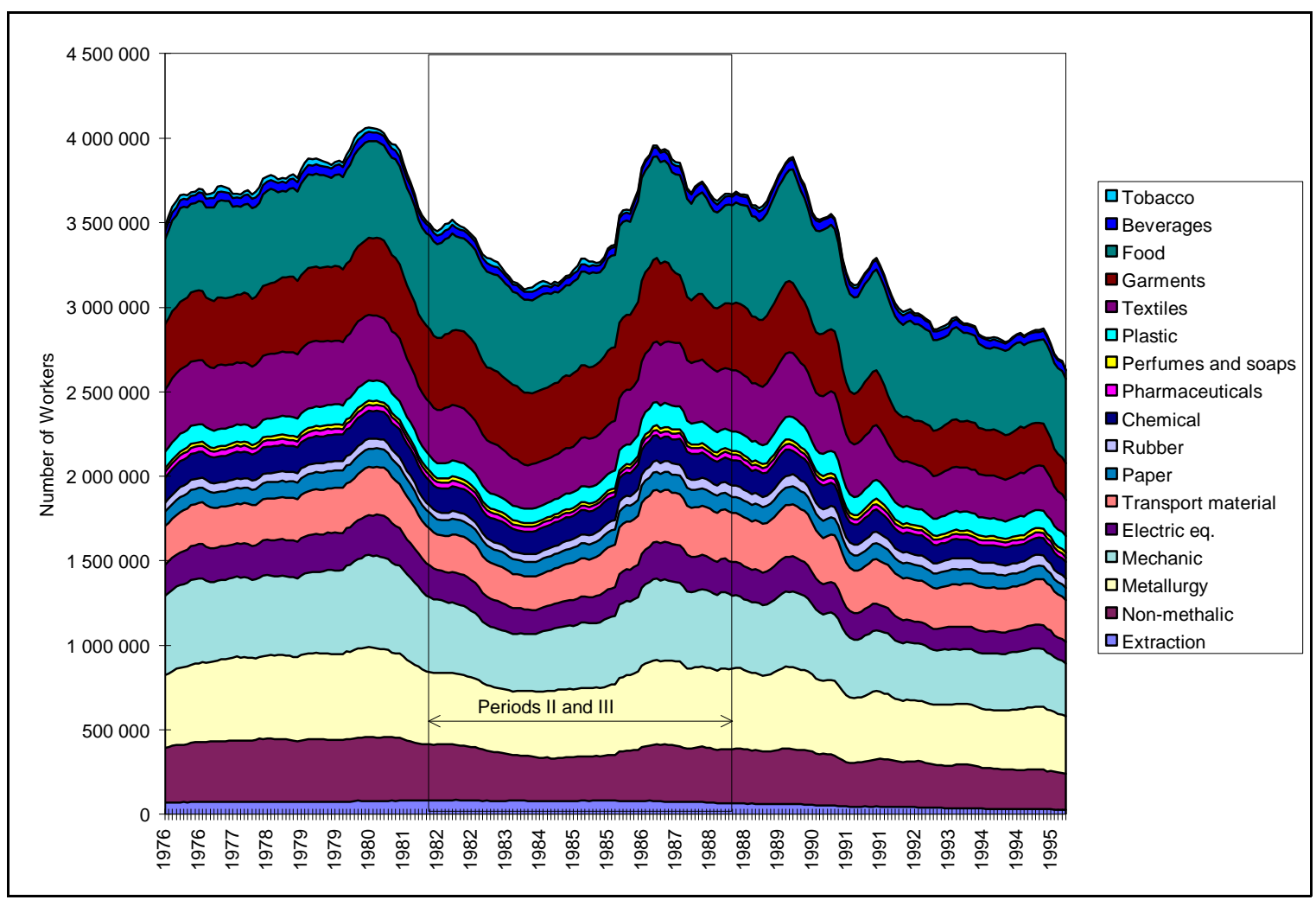

Figure 3- Evolution of the Employment Structure in Brazil 

Table 8 shows the changes in employment occurring during period II and during period III. Industries are ranked by average wage level.

Table 8- Changes in Employment Between 1981 and 1988

\begin{tabular}{lrr}
\hline \multicolumn{1}{c}{ Sectors } & \multicolumn{1}{c}{ Period II } & Period III \\
\multicolumn{1}{c}{ Ranked by Wage Level } & \%chg. $81-84$ & \%chg. $84-88$ \\
\hline Soap, perfumes, candles & $-16.67 \%$ & $20.97 \%$ \\
Tobacco & $-44.00 \%$ & $-54.28 \%$ \\
Pharmaceuticals & $-21.29 \%$ & $15.59 \%$ \\
Rubber & $-8.57 \%$ & $26.58 \%$ \\
Beverages & $-19.02 \%$ & $18.96 \%$ \\
Plastics & $-17.18 \%$ & $24.56 \%$ \\
Mineral Extraction & $-3.48 \%$ & $-19.97 \%$ \\
Paper & $-18.12 \%$ & $9.10 \%$ \\
Chemicals & $-15.05 \%$ & $0.46 \%$ \\
Electric and communication & $-36.88 \%$ & $26.11 \%$ \\
Transportation & $-20.34 \%$ & $29.22 \%$ \\
Textiles & $-27.78 \%$ & $27.94 \%$ \\
Non-metallic & $-31.24 \%$ & $21.22 \%$ \\
Steel & $-19.31 \%$ & $14.91 \%$ \\
Garments & $-5.55 \%$ & $-8.22 \%$ \\
Mechanical & $-28.83 \%$ & $10.66 \%$ \\
Food & $-6.21 \%$ & $8.99 \%$ \\
\hline
\end{tabular}

The relationship between fixed- and variable-weighted measures of industrial wage inequality enables us to decompose the change of industrial wage inequality into a purewage and an employment-composition component. By computing a 1995-weighted index for all years back to 1976, we can show that 39 percent of the total change in variableweighted inequality in Brazil is due to compositional effects such as the shrinkage of industries in the middle of wage structure, notably transportation materials, electrical equipment and the mechanical sector -- all of which were backbones of the former strategy of import-substituting industrialization. The remaining 61 percent of the rise in inequality is due to an increasing dispersion of wages across all sectors. And while our analysis shows that both the variable- and fixed-weighted series are sensitive to growth and stabilization, it is clear that the variable-weighted measure, which captures differential 
swings in employment shares that strongly affected industries in the middle of the wage structure in the 1980 s, is the more responsive to macroeconomic conditions.

This analysis also casts light indirectly on the process of restructuring in Brazilian industry, and particularly as the economy opened in the 1990s. We find that the events of the 1990s had more effect on the center of the wage structure than on the extremes. For this reason a Theil measure weighted by employment shares in 1976, when the center was more robust than it is today, rises much more rapidly in the 1990s than a measure weighted by actual employment. This suggests that while the most recent developments raised inequality, their impact was mitigated by the 20 -year decline in the middle of the wage structure that had already occurred. The opening of the Brazilian economy was thus the final act in the drama of debt crisis, recession and deindustrialization.

\section{4- Conclusions}

Contrary to a view that many students of Brazilian inequality appear to hold, we do not see evidence in our data that manufacturing wage inequality in Brazil is principally a matter of long-term trends or of social forces unrelated to economic conditions. Rather, we see a strong relationship between the evolution of this measure of inequality and macroeconomic developments in the country. We find that strong economic growth has been equalizing in Brazil, that the major increases in inequality correspond to periods of crisis and depression, and that the effects of high inflation appear to be principally on the movement of inequality from month-to-month rather than from year-to-year. Inflation raises inequality on a sustained basis only to the extent that inflation and recession are associated in Brazil.

We also find that changes in relative productivity of industries may be related to shifts in the trade regime. While opening influenced inter-industry wages mainly by increasing differentials toward the (diminished) middle of the wage structure, it had a 
much stronger effect on relative employment. In sharp contrast with the much more successful experience of Korea, we establish that in Brazil there exists a strongly negative relation between relative changes in productivity and relative changes in employment. In other words, increases in productivity are occurring simultaneously with decreases in labor demand. This is consistent with the view that rising average productivity in Brazil has been mainly a matter of the scrapping of inefficient and uncompetitive capital equipment, rather than of an increase in investment in advanced manufacturing.

These findings do not allow us to draw broad conclusions on the future path of wage inequality. It can only be said that macroeconomic developments and the restructuring process will jointly affect the future evolution of the Theil statistic for the Brazilian manufacturing sector. A closer look at the individual characteristics of workers in each industry and data relating exports, import competition, employment and wages, and a grasp on the sources of changes in productivity in the various sectors would allow a better understanding on the relation between inequality and the restructuring process.

However, as the restructuring process is ubiquitous, fast, and is clearly laborsaving, it is possible to speculate that it creates a bias toward further increases in overall inequality. If total employment in an industry tends to decrease rapidly, it is very unlikely that other sectors in the economy will be able to assimilate the unemployed. More than that, as most of the labor intensive industries are reducing employment, the potential for large and persistent unemployment seems to exist. Also, if productivity gains will not be transferred to labor, it is worth asking to whom are they being transferred? One possibility is that these gains are being transferred to prices, therefore creating an additional contribution to economic stability, which clearly favors the poor. But on the other hand, it is possible that these gains were being transformed into profits, which can either increase inequality directly, or else speed up the process of restructuring and lead, in Brazil's unhappy structural situation, to further increases of unemployment. 


\section{Acknowledgments}

We thank the Center for the Study of Western Hemispheric Trade for a generous grant in support of the research that led to this paper. We also thank the Ford Foundation, the Jerome Levy Economics Institute of Bard College and the Policy Research Institute of the University of Texas at Austin for their support of UTIP. Finally we thank our collaborators at UTIP, particularly Vidal Garza Cantú who has conducted much closelyrelated work on Mexico, and Qifei Wang, who designs and maintains the UTIP web-site.

\section{References}

Amadeo, Edward e José Márcio Camargo. 1991. "Mercado de Trabalho e Dança Distributiva” In Distribuição de Renda no Brasil. Ed. José Marcio Camargo e Fabio Giambiagi. Rio de Janeiro: Paz e Terra.

, 1996. "Instituiçoes e Mercado de Trabalho no Brasil". In Flexibilidade do

Mercado de Trabalho no Brasil. Ed. José Márcio Camargo. Rio de Janeiro: FGV.

Bonelli, Regis and Lauro Ramos, 1994. "Income Distribution in Brazil: an Evaluation of Long Term Trends and Changes in Inequality since the Mid-1970s.” In Estudos Sociais e do Trabalho. Ed. Rosane Mendonça e Andre Urani. Brasilia: IPEA.

Cardoso, Eliana. 1992 “Inflation and Poverty”. NBER Working Paper, No. 4006.

Kim, Dae-Il and Robert H. Topel, 1995. 'Labor Markets and Economic Growth: Korea’s Industrialization.”. In Differences and Changes in Wage Structures. Ed. Richard Freeman and Lawrence Katz. Chicago: University of Chicago Press.

Langoni, Carlos, 1973. Distribuição de Renda e Crescimento no Brasil. Rio de Janeiro: Editora Expressão e Cultura. 
Leal, Carlos Simonsen and Sergio Werlang. 1991. "Educação e Distribuição de Renda" In Distribuição de Renda no Brasil. Ed. José Marcio Camargo e Fabio Giambiagi. Rio de Janeiro: Paz e Terra.

Pinheiro, A et alli 1993. "Incentivos Fiscais e Creditícios as Exportações: Resultados Setoriais para o Período 1980-91". Texto para Discussão n.300. Rio de Janeiro: IPEA.

Ramos, Lauro, 1993. A Distribuição de Rendimentos no Brasil 1976/85. Série IPEA, 141 Rio de Janeiro: IPEA , 1995. "Interindustry Wage Differentials". Texto para Discussão n.374. Rio de Janeiro: IPEA.

Saboia, João, 1991. "Politica Salarial e Distribuição de Renda: 25 anos de Desencontros". In Distribuição de Renda no Brasil. Ed. José Marcio Camargo e Fabio Giambiagi. Rio de Janeiro: Paz e Terra.

Silva, Salomão. "Sistema Financeiro, Participação na Renda, Funções e Disfunções” In Distribuição de Renda no Brasil. Ed. José Marcio Camargo e Fabio Giambiagi. Rio de Janeiro: Paz e Terra. 